\title{
GLOBALIZATION TOURISM PROMOTION FOR TOURISM PLACES TG.PINANG AS THE WORLD TOURISM \\ (International Seminar)
}

\author{
By Seno H Putra, Drs.,M.Pd., Ph.D.,Prof \\ The Islamic University of Riau, Pekanbaru, Indonesia \\ seno@edu.uir.ac.id \\ Seno H Putra. Abstract: Globalization Tourism Promotion, Culture,Natural \\ Tourism Objects, Home Industry,Local Products,Infrastructure, and \\ Services.
}

\begin{abstract}
Tg.Pinang as the Capital City of Riau Archipelago particularly and other its areas, generally have a lot of potencies of Tourism Objects whether Natural Objects, Cultural Objects, Historical Objects, Sea and Beach Objects, Home Industry, etc. Therefore, because of these, it is needed to be maintained, built, developed, innovated, and promoted to Local, National, Asean, Asia, and Global Promotions, so that those can be known or be famous for Global Community. These assets can also be deficits of Local, National, and the welfare of Society.Consequently, to do these as good as possible, it is needed, such as good promotion, infrastructures, services, and exchange exhibitions in Local, National, Asean, Asia, and Global Communities.
\end{abstract}

\section{Background of the Problem}

Tg. Pinang as a the Capital City of Archipelago Province, where this Province has some potencial issues to develop its own area. First, this area is very close to Singapore, Johor, Malaysia, and Pekanbaru as a Mainland Province; Second, It also has a lot of Natural Sources, such as Gas in Natuna, Fish, Tin, etc., serounding its Province, Like besides Natuta, Tg. Balai Karimun, Batam, Tg. Batu, Moro, and others; and Third, this Province also encompasses many Tourism Places not only Beaches, but also historical Places, such as Penyengat, etc.

Therefore, besides as mentioned above, after reformation era, this region was separated from the Mainland Province, so, this area was to be independence and performed its Province. After this area became its Province, the Government and its Society started to develop this area and its other Regencies, such as infrastructures, harbours, Human sources, Schools, Academy and 
Universities, Department Stores, Mall, Restaurants, Malay Cultures, Malay Language and English, etc., including Tourism Places whether Natural Tourism Places or Historical Tourism Places.

In addition to this, historically, most of Tg. Pinang and its Regencies, in which its Community (Society) since a long time ago until at present, they still maintain their own Language and Culture, that is, Malay. This can be proved that People in here still use Malay Language and Malay Culture as their own characteristics in daily life in non formal setting, such as in homes, Markets, and certain Places of the Community.

\section{Literary Review}

Tourism Places in Indonesia is one of assets and capital incomes which have important roles to increase deficit surplus of States besides other sources. Therefore, the Indonesian Government has supported this potency to develop and promote based own its characteristics of each local potency to become National Potency.

Indonesia as areas Archipelago, certainly, from Sabang to Merauke has a lot of Tourism Objects, which can invite investors to build them, to support, develop, and call on the local and foreign tourisms to come and stay there, as well as to promote these objects to global Communities.

The Rules of Indonesian Government Number 10 the Year 2009 based on Ideology of Pancasila and the Opening of the basic 45 Indonesian Institutions stated that the Potency of Indonesian Natural whether Local and National ones must develop and become local and National Tourism objects for Indonesia People welfare. This idea is also supported by the Rules of Indonesian President Number 63 section 1 and the Year 2014, the Tousrism Places (Objets) in Indonesia must support with the good services, Infrastrucrures, and good Transportations. 


\section{A Little Issues of Malay In the Use of Malay Language}

Belwood (1995) in Nothofer (1996) in Seno (2004) claimed that people who spoke Austronesian Languages setteled in Sumatra perhaps by 1000 BC. He then assumed that Austronesian immigrants who lived in those islands of Southeast Asia used a language. Therefore, it was considered that about $500 \mathrm{BC}$, the Malay Language had developed in Western Coastal of Borneo. Belwood, in this case, also concluded that the first wave of immigrants who spread to Western Borneo forward to Riau and Middle Sumatra perhaps 2000 years ago used old Malay language. Related to this, Adelaar (1988) in Seno (2004) stated that Malayic isolects are settled in th island of Borneo and there (Borneo) Malayic variants show no or little influence from Sankrit or Arabic.

Collins (1998) in Seno (2004) proposed that because of their advanced water technology, proto Malay Speakers moved at an early period, perhaps before $100 \mathrm{BC}$, westward across the South China Sea through the Tembelan and Riau Islands to Sumatra, and from there, to the southernmost extention of the Asian mainland, now known as the Malay Peninsula. Blust (1998) in Seno (2004) also explained that among the descendants of ProtoMalay, we surely would wish to include that standard form of Malay which serves as the basis of the national languages of Malaysia and Indonesia. He also wrote that Borneo forms of Malay which became established as Lingua franca in the principal enrepots of island Southeast Asia prior to the arrival of the Portuguese in the $16^{\text {th }}$ century; such structurally diverse forms of speech as Banjarnese, Sarawak and Brunei Malay, Jakarta Malay, Kupang Malay, Makasar Malay, Menado Malayo and Ambon Malay.

\section{Culture}

Culture is the creativity of human whether individual, a group, or the broad society, which expresses through out personality, behavior, attitude, ethics, norms, values, etc., in the forms of concrete or abstract based on the habits, then those can become culture specifically and 
universally carrying out the conventional processes that can be accepted by the largest society (Seno Putra,2008).

Culture is based on the personality behavior, a group, or the largest community, in which the application of culture for human life can be divided into three types, that is; Local Culture, State/Nation Culture, and Global Culture. Local Culture is the individual and its society both abstract and concrete, the culture that they have must be maintained, developed, and socialized from one generation to the next generation, so that culture does not loose from human civilization, and this culture can also support National culture as various cultures of the Country.

\section{Discussion}

As mentioned above, Riau Archipelago has a lot of Natural Potencies, such as Beach, Sea, Historical Places, Fall Water, etc., and also Malay Culture. These objects can be found in each area of Riau Archipelago, like in Tg.Pinang, Tg. Balai Karimun, Tg. Batu, Tg. Uban, Natuna, Terempa, Moro, Batam,etc. Besides this, this Riau Archipelago also has Primitive People called as Sea People (Sea Tribes). This Tribe People still maintain their lifes in the Sea or sea side, for examples, they have still heritage their own Language, Cultures, economy, Demography since a long time ago until at present (Seno's Survey and Journeys).

\section{a.Malay Culture as Asset Indonesian, Asean, Asia, and Global}

The Culture as human civilization, in which It features different kinds of cultural from heritage of many nationalities, societies, and ethnic groups in the region, traditionally called a continent from a Western-centric perspective. The Region or "Continent" is broad in geography, in this case, we only focus on $\mathrm{Tg}$. Pinang and its

Regencies as Riau Archipelago, where these areas has many its own cultures, for examples; Malay music, art, dance, cuisine, as well as literature are important parts of Malay culture as Raja Ali Haji at the Penyengat Island.

Unfortunately, this richness in culture and art seldom explore in order to introduce and promote to Asean and Global ones. Malay 
cultures belong to these areas, actually, can maintain, promote, and also can be as tourism objects. Traditional Cultures, such as dances, songs, music, food, home Industry, cake, etc., including historical places as tourism objects of each area must maintain and promote not only to among Indonesia Regions, Asean, Asia Country Community, but also to all over the World, so that these traditional cultures can be known by the people in the World (Seno Putra, 2008).

The National culture is the collection and various Local cultures to be National asset, which also can be maintained, developed, and socialized, as well as being the contribution of Nation and state for the global world. While, global culture is various creativities, innovations, etc., in the human civilization and various cultures in the world, so that the global cultures in one side that can be accepted, and the other sides can be rejected depending on the society that evaluate them (Seno Putra,2006).

\section{b. Malay, Indonesian, Language, and (English)}

From a child until passed away, human beings in the world use and apply the Language in their life activities. The Language used by them, of course, depends on their mother tongue, or certain community, where the language used. So, Many various Languages or Dialects created by the God in the world starting from Adam Prophet until at the present Human, they use their own languages certainly to send the messages both spoken, written, formal, and non formal setting between Speaker and Listener (Audients), as well as through out telephone whether close or long distance, all these function to communicate one another and to have mutual Understanding (Seno Putra,2001-2013).

Most of these Areas (Riau Archipelago) in non-formal setting use Malay Language since a long time ago up to present. They use this Language, for examples, at Home (Family), friends, Wedding Party, in the Markets, at the Harbours, at the Restaurants, Public Transportations, etc., to have communication among them in there; while, for formal setting, people in here use Indonesian Language, such as at Schools, Offices, Ceremony, etc. 
However, English a little bit use in here, if there is, it is only (5 0r 10 percent) of the people use English, it is especially to guide and communicate with the foreign Tourists who visit the Tourism Places and stay in here. English is used by them only in the places, like at Tourism Objects, Hotels, Harbour, Immigration Office, Customs Office; while in the trades or Markets, it is seldom used (Seno's Survey and Journey).

\section{c. Services, Infrastruture Building, Public Transportation, Home-Stay, Cottage, and Hotels.}

1. Besides other devices of Tourism Needs, services are needed to support Tourism as non-formal or formal ones, for instance, the Officers of Immigration and Customs must serve them as good as possible, and the they must understand English. The Porters in the Harbours must also serve them as good as possible, at least they also can speak English; the crews of the ships are expected to be good service to them; the workers of the hotels and others not only can speak English with them, but they must also understand how to serve the tourists with good ways, such as wearing Malay Dress, ethics, norms, values, etc., of Malay must be maintained to show Riau Archipelago's Culture; and the Translators and the Guiders must also prepare and be ready to accompany them any ways of Tourism Places.

2. The building of Infrastrures, besides Harbour Innovations, and the Roads must be built, be good, and clean to reach the Tourism Objects, but not many Roads' Holes; and so that the Public Transportations whether ships, Bus, or Mini Cabs, etc., including Flight must be good and clean, because these also support the convertability of Tourists.

\section{Conclusion and Recommendation}

As we have discussed above that the building, developing and promoting the Tourism Objects at Archipelago Province to be Local, National, Asean, Asia, and Global must be routine, and continuously from year to year. This case in one side can be asset of Local and National, as well as to increase the People's welfares. 
Therefore, I conclude and recommend as follows: 1) all Natural objects of Tourism in Tg.Pinang especially, and Riau Archipelago, generally must build, Innovate, develop, promote to be Local, National, Asean, Asia, and Global; 2) the Infrastructures of each Tourism Object in Riau Archipelago must build and innovate, this can be done by working together among Local Government, Investors, and society; 3) Historical views of Tourism Objects in these areas must maintained and innovated, in which they can be their own characteristics; 4) Malay Culture and Language must also be maintained, so that they can show their own characteristics, and this must show to the Tourists; 5) other games of Local Society, traditional dances, songs, poetry, proverbs, food, sea food, cakes, and other sourvernirs, etc., must also be maintained, and these must be prepared,developed, and promoted to the Tourists; 6) the services of Buroucracy, crews of the ships, Harbour porters, Interpreters and Guiders, in Home Stay, Cottages, Hotels, etc., must be good as possible; and 7) any cultures exchange, including Local Products and home Industries among Asean, Asia, and other Countries to support and promote the Riau Archipelago tourism objects to be famous in Global.

\section{References}

Seno Putra.2006. Berbual dalam Wacana Orang Melayu.Pekanbaru: Suska Press.

Seno Putra.2001. Introduction to Linguistics.Pekanbaru:Unri Press.

Seno Putra.2008. Menggali Potensi Budaya Propinsi Riau.Pekanbaru:

Litbang Riau.

Seno Putra.2006. Morphosyntax.Pekanbaru: Suska Press.

Seno Putra.2004. Linguistics and Science and Technology.Pekanbaru: Reset Riau.

Seno Putra.2006. Potensi Kebudayaan Bonai.Pekanbaru:Caltex.

Seno Putra.1999. Beberapa Piranti dalam Sosiolinguistik:Makalah Nasional.Pekanbaru.

Seno Putra.2001.Masyarakat Melayu Purba.Internasional Makalah.Malaysia:UKM

Seno Putra.2006. Morphology of TM Dialect.Pekanbaru:Suska Press.

Seno Putra.2012. Linguistics and TEFL. Internasional Makalah.

Seno Putra.2011.Lintas Bahasa dan Budaya Indonesia dan Malaysia: Internasional Makalah. Pekanbaru:UIR

Seno Putra.2007.Pandangan dan Masyarakt TM.Jurnal Siasat.Pisipol UIR.

Seno Putra, 1999.Renungan dan Sikap Masyarakat Riau di Era Reformasi.Pekanbaru:UIR Press.

\section{Seno H Putra, Inhu, August 67}

Pure Linguistic Professor of Teacher's Training and Education Faculty, the Islamic University of Riau, Pekanbaru, Indonesia.

The First University (TEFL) (1991);

Master Degree (English Linguistics) (1997);

P.hD (Pure Linguistics) (2004); and

Professor (Pure Linguistics) (2007). 
